\title{
Penyakit Ginjal Polikistik disertai Anemia Hemolitik Autoimun
}

\author{
Yosa Tamia Marisa ${ }^{1 *}$, Harnavi Harun ${ }^{2}$ \\ Bagian Penyakit Dalam RSUP. Dr. M Djamil Padang ${ }^{1}$ \\ Sub-bagian Ginjal Hipertensi RSUP Dr. M Djamil Padang ${ }^{2}$ \\ *e-mail: yossamarisa@gmail.com
}

\begin{abstract}
Abstrak
Penyakit ginjal polikistik (PKD) terdiri atas autosomal dominan PKD (ADPKD) dan autosom resesif PKD (ARPKD). ADPKD adalah gangguan multifaktorial yang bercirikan kista ginjal bilateral dan umum menyerang pasien dewasa. Kista hepar adalah manifestasi ekstrarenal yang paling umum dari ADPKD dan sering merupakan temuan insidental dan secara klinis yang tidak signifikan. Telah dilaporkan sebuah laporan kasus dengan penyakit polikistik di ginjal dan hepar disertai anemia hemolitik autoimmun pada seorang pasien wanita usia 62 tahun. ADPKD merupakan penyakit progresif dan gejala cenderung memburuk seiring waktu. Perawatan untuk ADPKD melibatkan pengelolaan gejala dan memperlambat perkembangan penyakit. Komplikasi ADPKD yang paling serius adalah gagal ginjal tahap akhir. Penelitian ini bertujuan untuk mengetahui gejala dan pemeriksaan laboratorium yang menegakkan diagnosis penyakit ginjal polikistik disertai anemia hemolitik autoimun.
\end{abstract}

Kata Kunci: penyakit ginjal polikistik, kista hepar, AIHA, ADPKD

\section{Polycystic Kidney Disease with Anemia Hemolytic Autoimmune}

\begin{abstract}
The hereditary forms of polycystic kidney disease of autosomal dominant PKD (ADPKD) and autosomal recessive PKD (ARPKD) are the main forms. ADPKD is a multifactorial disorder characterized by bilateral renal cysts and commonly affects adult patients. The most common extrarenal manifestations of ADPKD are liver cysts and is often incidental findings and clinically insignificant. A case report has been reported with polycystic disease in the kidneys and liver with autoimmune hemolytic anemia. ADPKD is a progressive disease and symptoms tend to get worse over time. ADPKD involves managing the symptoms and slowing disease progression. The most serious complication of ADPKD is end stage kidney failure. This aim of this study was to determine the symptoms and laboratory tests that confirm the diagnosis of polycystic kidney disease accompanied by autoimmune hemolytic anemia.
\end{abstract}

Keywords: Polycystic Kidney Disease, liver cyst, AIHA, ADPKD

\section{PENDAHULUAN}

Polikistik berasal dari dua kata poly yang berarti banyak dan Cystic yang berarti rongga tertutup abnormal, dilapisi epitel yang mengandung cairan atau bahan semisolid, jika digabungkan polikistik berarti banyak kista. Penyakit polikistik merupakan salah satu penyakit polikistik herediter yang 
jarang, dapat melibatkan satu atau beberapa organ. Penyakit hati polikistik sering bersamaan dengan polikistik ginjal autosomal dominan atau autosomal dominant polycystic kidney disease (ADPKD). Sebanyak 50\% pasien dengan ADPKD mempunyai kista hati (Vachha et al, 2011). Kista ginjal dapat disebabkan oleh anomali kongenital ataupun kelainan yang didapat. Kista ginjal dibedakan menjadi ginjal multikistik diplastik, ginjal polikistik, dan kista ginjal Soliter (Purnomo, 2009).

Protein yang berperan pada penyakit hati polikistik disebut hepatocystin yang dikode oleh gen PRKCRH, terdapat pada kromosom 19p dan gen SEC63 pada kromosom 6q. sedangkan pada penyakit polikistik ginjal kelainan gen utama adalah PKD-1 dan PKD-2.

ADPKD paling sering disebabkan oleh perubahan pada gen PKD1 dan PKD2 (Chebib and Tores, 2018).

Manifestasi klinis ADPKD tidak menunjukkan gejala hingga dekade keempat. Nyeri yang dirasakan tumpul di daerah lumbar merupakan tanda terjadinya iritasi di daerah peritoneal akibat kista yang ruptur. Nyeri yang terjadi secara konstan merupakan petanda dari perbesaran satu atau lebih kista. Gross Hematuria terjadi ketika kista yang ruptur masuk kedalam pelvis ginjal. Hematuria mikroskopi lebih sering terjadi dibanding gross hematuria dan merupakan indikasi masalah ginjal yang lebih serius. Hipertensi ditemukan dengan derajat yang berbeda pada $75 \%$ pasien ADPKD (Ettorre et al, 2012).

Pengobatan pada ADPKD bersifat suportif dimana pengobatan ini dapat berkembang progresif bila terjadi gagal ginjal yang memungkinkan dialisis dan trasplantasi ginjal. Penatalaksanaan ini bertujuan untuk mencegah komplikasi dan memelihara fungsi ginjal. Tindakan bedah dengan memecah kista tidak banyak manfaatnya untuk memperbaiki fungsi ginjal (Ong et al, 2010).

Komplikasi penyakit polikistik diantaranya pielonefritis. Infeksi sekunder pada kista dapat memberi keluhan nyeri pinggang yang hebat, kista yang semakin besar akan menekan parenkim ginjal akibatnya terjadi iskemia dan menurunkan perlahan fungsi ginjal secara perlahan. Hipertensi dapat terjadi karena iskemia jaringan ginjal yang menyebabkan peningkatan renin angiotensin (Ong et al, 2010).

Pada penyakit polikistik, mutasi pada PKD-1 ataupun PKD-2 meyebabkan makrofag di darah (monosit) menginfiltrasi jaringan. Hal ini terjadi karena adanya kegagalan regulator dari imun nonspesifik di darah. Hal serupa juga terjadi pada sistem hematopoietic yang berlanjut dan menyebabkan fragmentasi dari sel eritrosit 
oleh antibodi dan makrofag (Kelton et al, 2011). Hal ini menyebabkan hemolisis sel darah merah autoimun atau yang biasa kita kenal AlHA. Anemia hemolitik autoimun adalah suatu kelainan dimana terdapat antibodi tertentu pada tubuh yang menganggap eritrosit sebagai antigen nonselfnya sehingga menyebabkan eritrosit mengalami lisis (McPhee and Papadakis, 2010).

Ada 2 mekanisme yang menyebabkan terjadinya anemia hemolitik autoimun, yaitu aktivasi komplemen dan aktivasi mekanisme seluler, atau kombinasi keduanya. Defisiensi isozim piruvat kinase yang ditemukan dalam sel darah merah menimbulkan anemia hemolitik. Piruvat kinase adalah enzim kunci dalam glikolisis. Enzim ini berfungsi untuk katalisator dan menghasilkan ATP. Defisiensi piruvat kinase menyebabkan penimbunan zat antara glikolisis sehingga kemampuan mengangkut oksigen oleh darah akan berkurang. Penurunan pembentukan ATP akan menyebabkan gangguan pada pompa kation di membran sel sehingga kalsium akan masuk ke dalam sel, sementara kalium dan H2O akan keluar sel. Hal ini menimbulkan dehidrasi dan eritrosit akan difagositosis oleh sel-sel limpa (Kalyani et al, 2012).

Untuk mendiagnosis anemia hemolitik dilakukan pemeriksaan Coomb's test. Ada 2 cara, yaitu direct Coomb's test. Sel eritrosit pada pasien dibersihkan dari protein-protein yang melekat pada eritrosit, lalu direaksikan dengan antibodi monoklonal seperti IgG dan komplemen C3d. Jika terjadi aglutinasi maka hasilnya positif. Artinya IgG atau C3d atau keduanya melekat di eritrosit tersebut. Indirect Coomb's test. Serum pasien diambil, direaksikan dengan sel-sel reagen yaitu sel darah merah yang telah terstandar. Jika terjadi aglutinasi maka hasilnya positif. Artinya ada imunoglobulin di serum tersebut yang bereaksi dengan sel-sel reagen (Schwartz et al, 2011). Terapi yang dapat diberikan pada anemia hemolitik autoimun adalah glukokortikoid, dan splenektomi pada kasus yang tidak berespon dengan pemberian glukokortikoid (Kelton et al, 2011).

\section{PRESENTASI KASUS}

Telah di rawat seorang pasien wanita berumur 62 tahun di Bangsal Penyakit Dalam RSUP Dr. M. Djamil Padang dengan :

Keluhan Utama: Perut kanan atas yang semakin membengkak sejak 2 minggu yang lalu.

Riwayat Penyakit Sekarang: perut kanan atas yang semakin membengkak sejak 2 minggu yang lalu. Nyeri pada perut kanan atas sejak 1 bulan yang lalu, nyeri dirasakan hilang timbul, nyeri kadang menjalar ke punggung kanan. Perut terasa cepat penuh dan kenyang sejak 1 bulan yang lalu. Badan terasa lemah dan letih sejak 3 minggu yang 
lalu, pasien juga merasakan semakin pucat dalam 3 minggu ini. Nafsu makan berkurang sejak 2 minggu yang lalu. Mual ada, muntah tidak ada sejak 4 hari yang lalu. Pasien telah berobat 4 hari yang lalu di RSUD dan telah dilakukan USG dengan hasil polikistik hati, pasien kemudian dirujuk ke M Djamil untuk penatalaksanaan lebih lanjut. Sesak nafas tidak ada. Mata kuning tidak ada. Penurunan berat badan tidak ada. Demam tidak ada. Batuk tidak ada. Nyeri pinggang tidak ada. Riwayat mimisan tidak ada, muntah darah tidak ada, buang air besar hitam tidak ada. Riwayat buang air kecil berwarna seperti teh pekat tidak ada. Riwayat buang air besar keluar cacing tidak ada, buang air besar pucat seperti dempul tidak ada. Riwayat mencret-mencret sebelumnya tidak ada. Buang air besar dan buang air kecil jumlah dan konsistensi biasa

\section{Riwayat Penyakit Dahulu}

Riwayat sakit kuning sebelumnya tidak ada. Riwayat sakit paru-paru sebelumnya tidak ada. Riwayat nyeri perut seperti ini sebelumnya tidak ada

\section{Riwayat Pengobatan}

Riwayat minum obat penghilang rasa sakit dalam jangka waktu lama dan jamujamuan sebelumnya tidak ada. Riwayat minum obat 6 bulan sebelumnya tidak ada. Riwayat tranfusi darah sebelumnya tidak ada.

\section{Riwayat Penyakit Keluarga}

Tidak ada keluarga pasien yang mempunyai penyakit yang sama dengan pasien

Riwayat Pekerjaan, ekonomi, kebiasaan, dan perkawinan

Pasien adalah seorang petani. Riwayat terpapar insektisida ada, riwayat terpapar radiasi tidak ada. Kebiasaan suka makan kacang-kacangan tidak ada.

Pasien tidak merokok, tidak pernah minum alkohol

Pasien datang dalam Kesadaran: Composmentis cooperative Tekanan darah: $120 / 70 \mathrm{mmHg}$, Nadi: $86 x / m e n i t$, teratur, pengisian cukup, Nafas: 20x/menit. Suhu: $36,6^{\circ} \mathrm{C}$. Keadaan umum: baik

Keadaan gizi: baik. Berat badan: $50 \mathrm{~kg}$. Tinggi badan: 155 cm. BMl: 20.83 (normoweight). Anemis: (+). Sianosis: (-). Pada pemeriksaan fisik Hepar teraba 4 jari $B A C, 3$ jari bawah procesus xipoedeus pinggir tumpul, permukaan rata, konsistensi kenyal, fluktuasi (+) nyeri tekan (-) dan lien SO, ballottement (-/-).Punggung: nyeri tekan, nyeri ketok sudut Costo Vetebre Angel tidak ada.

Pada pemeriksaan laboratorium didapatkan Hemoglobin: 7,5 gr/dl. Hematokrit: 23 \% Leukosit: 6.900/mm3. Trombosit: $256.000 / \mathrm{mm} 3$. LED: $30 \mathrm{~mm} / \mathrm{jam}$. Hitung jenis: 0/3/0/71/22/4. Gambaran darah tepi, Eritrosit: normositik normokrom, 
ISSN 1978-2071 (Print); ISSN 2580-5967 (Online) Jurnal IImiah Kedokteran Wijaya Kusuma 10(1): 102-111, Maret 2021

polikrom (+) Leukosit: jumlah cukup, morfologi normal Trombosit: jumlah cukup, morfologi normal. MCV: 84fL MCH: 28 pg, MCHC: 33 \% Retikulosit: 2,6 \% Ureum: 16 mg/dl, Creatinin: 1,1 mg/dl, SGOT/SGPT: 21/13 u/l, Total protein: 6,0 gr/dl Albumin: 3,0 g/dl, Globulin: 3,1 gr/dl, GDS: 102 mg/dl Bilirubin total: 0,8 mg/dl, Direk comb tes (+), HbsAg: nonreaktif, Anti Hcv: negatif, LDH: $276 \mathrm{u} / \mathrm{l}$.
Pada pemeriksaan Ultrasonografi (USG) abdomen didapatkan kesan hati membesar, permukaan rata, parenkim homogen, halus, pinggir tajam, vena tidak melebar, duktus biliaris melebar, vena porta normal. Kandung empedu: dinding tebal, batu $(+)$, Pankreas: normal, Lien: tidak membesar, ginjal polikistik bilateral seperti yang terlihat pada Gambar 1.

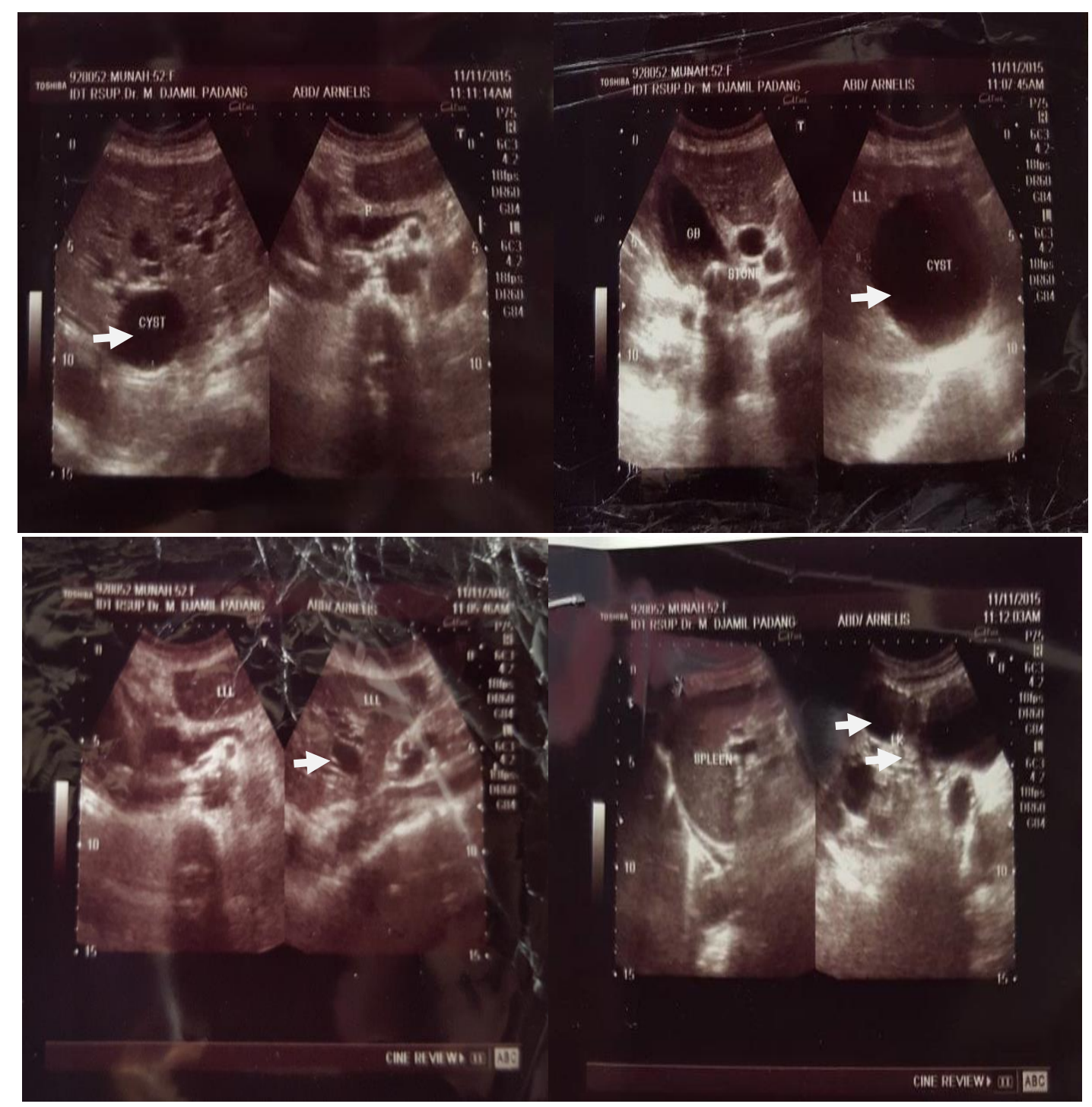

Gambar 1. Pemeriksaan Ultrasonografi pada Abdomen 


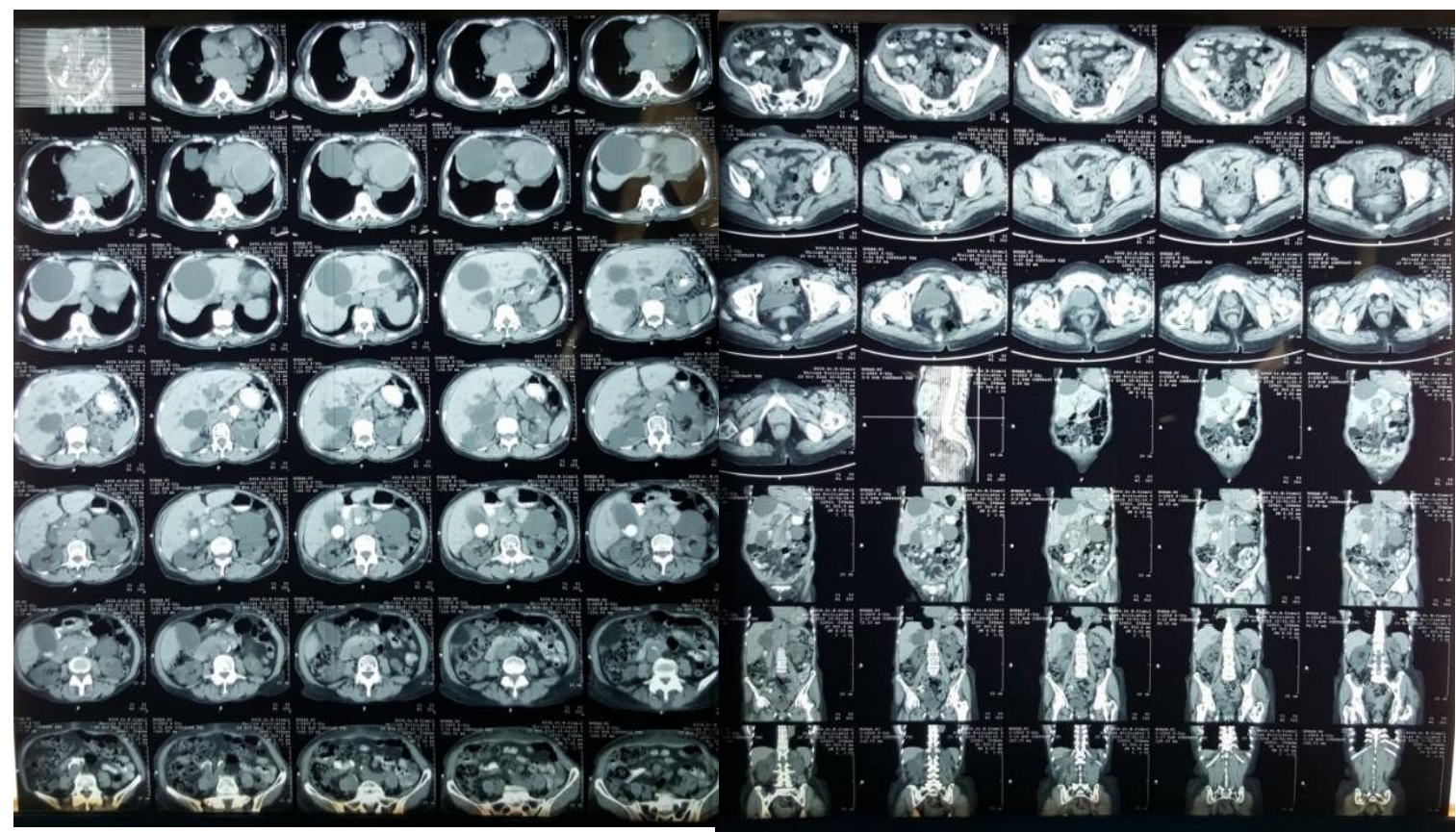

Gambar 2. Pemeriksaan Computed Tomography (CT) Scan Abdomen

Hasil CT scan pada abdomen memberikan kesan: Kista hepar multiple, Polycystic kidney disease bilateral, Dilatasi bilier intra dan ekstrahepatal ec batu CBD, Kolelitiasis dan kolesistitis.

\section{DISKUSI}

Telah dilaporkan seorang pasien wanita berumur 62 tahun yang dirawat di bangsal Penyakit Dalam RSUP Dr. M. Djamil Padang dengan diagnosis penyakit ginjal polikistik, anemia sedang normositik normokrom ec hemolitik ec autoimun, kolesistitis dan kolelitiasis. Kasus ini cukup menarik karena penyakit polikistik cukup jarang ditemukan.

Diagnosis akhir pada pasien ini ditegakkan dari serangkaian pemeriksaan meliputi anamnesa, pemeriksaan fisik dan pemeriksaan penunjang. Pada pasien ini dari anamnesa didapatkan pembesaran perut kanan atas yang meningkat sejak 2 minggu yang sudah dirasakan sejak 2 bulan yang lalu. Pembengkakan perut kanan atas ini disertai dengan nyeri yang hilang timbul. Dari pemeriksaan fisik kami menemukan hepatomegali dengan konsistensi yang kenyal dan adanya fluktuasi. Dari pemeriksaan laboratorium tidak terdapat peningkatan fungsi hati. Hasil pemeriksaan USG abdomen pada pasien ini ditemukan multipel kista pada hepar dan polikistik ginjal dan telah dikonfirmasi dengan pemeriksaan CT Scan Abdomen dengan kontras yang mengarahkan adanya suatu ADPKD. Anjuran biopsi ginjal maupun pemeriksaan gen bisa memperkuat diagnosis, pada pasien ini tidak dilakukan 
karena keterbatasan sumberdaya.

Pemeriksaan Imaging cukup mendiskirpsikan diagnosa pada pasien ini dan tata laksana ditekankan pada terapi suportif dan simptomatik.

Penyakit polikistik pada pasien ini ditegakkan karena ditemukan penyakit ginjal polikistik dan polikistik hepar. Pada literatur disebutkan bahwa ada dua bentuk polikistik ginjal yaitu bentuk dewasa yang bersifat autosomal dominan atau ADPKD dan bentuk anak-anak yang bersifat autosomal resesif atau ARPKD (Vachha et al, 2011). Pada pasien ini diduga dalam bentuk yang pertama. Penyakit ginjal polikistik dominan autosomal (ADPKD) merupakan penyakit sistemik dan progresif yang ditunjukkan dengan pembentukan dan pembesaran kista di ginjal dan organ lain antara lain hati, pankreas dan limpa (Purnomo, 2009).

Ada 3 bentuk dari penyakit ginjal polikistik dominan autosomal yaitu tipe-1 yang merupakan $90 \%$ kasus dan gen yang bermutasi pada kromosom nomer 16 lengan pendek; tipe-2 terletak pada kromosom nomer 4 lengan pendek; tipe-3 belum diketahui gen yang bertanggung jawab (Lee et al, 2011).

Dalam literatur disebutkan bahwa prevalensi penyakit ginjal polikistik dominan autosomal 1:1000 individu dan $10 \%$ diantaranya mengalami penyakit ginjal kronis dan hampir $50 \%$ diantaranya menjalani terapi hemodialisis pada usia 60 tahun keatas. ADPKD tidak menimbulkan gejala hingga akhir dekade keempat (Chebib and Torres, 2018).

Pada umumnya terdapat dua gen yang berperan terhadap terbentuknya kista yaitu PKD-1 yang terletak pada lengan pendek kromosom 16, dan PKD-2 yang terletak pada lengan pendek kromosom 4. PKD-1 mengkode protein polikistin-1 yang diketahui berperan dalam perlekatan sel ke sel atau sel ke matriks. Gen PKD-2 mengkode polikistin-2 yang bersama dengan PKD-1 membentuk heterodimer. Belum diketahui bagaimana mutasi pada protein tersebut menyebabkan kista. Gangguan interaksi antara sel-matriks diduga dapat menyebabkan gangguan pada pertumbuhan, diferensiasi dan pembentukan matriks oleh sel epitel tubulus dan menyebabkan terbentuknya kista (Lee et al, 2011).

Penyakit polikistik hepar memiliki hubungan dengan penyakit polikistik ginjal. Literatur menyebutkan bahwa 1 dari 5 orang dengan penyakit polikistik ginjal autosomal dominan pada usia diatas 30 tahun mengalami penyakit polikistik hepar. Ada dua gen yang berperan dalam terjadinya polikistik hepar yaitu hepatocystin yang dikode oleh gen PRKCSH, terdapat pada kromosom 19p dan gen 
SEC63 pada kromosom 6q. Secara epidemiologi angka kejadian dari penyakit hati polikistik tersebut adalah 1:100.000 sampai dengan 1:1.000.000/ tahun. Asimptomatis atau tanpa gejala seringkali terjadi atau gejala baru dirasakan pada dekade ke empat kehidupan. Angka kejadian ADPKD terbanyak pada wanita dibandingkan pria. Pada penyakit hati polikistik dapat terjadi kolestasis baik intra maupun ekstra hepatal, dimana terbentuknya kista hepar diduga karena defek kongenital dari sistem bilier pada ADPKD. Sampai saat ini belum ada mekanisme pasti menjelaskan hal tersebut. Pada pasien ini, terjadi obstruksi parsial kronik pada sistem bilier dan hal ini menimbulkan peradangan (kolesistitis) dan peradangan kronik ini akan mencetuskan terjadi batu pada empedu tersebut sesuai dengan teori inflamasi (Chebib and Torres, 2018).

Diagnosis anemia sedang normositik normokrom ec hemolitik ec autoimun terjadi pada pasien ditegakkan dengan adanya keluhan pucat, badan letih lesu dari pemeriksaan ditemukan $\mathrm{Hb}: 7,5 \mathrm{mg} / \mathrm{dl}$ dengan gambaran darah tepi normositik normokrom dengan polikromasi. Menurut kriteria WHO kisaran $\mathrm{Hb}<8 \mathrm{gr} / \mathrm{dl}$ dan $\mathrm{Hb}>6$ $\mathrm{gr} / \mathrm{dl}$ termasuk anemia sedang. Pada pemeriksaan retikulosit didapatkan nilai 2,6 $\%$ dan dari pemeriksaan Coomb's tes didapatkan hasil direct comb test positif. Penegakkan diagnosis ini telah sesuai dengan alur diagnosis anemia hemolitik autoimun. Pemeriksaan direct Coomb's test memiliki spesifisitas $98 \%$ untuk mendeteksi AlHA. Hasil yang positif menunjukkan adanya imunoglobulin yang melapisi permukaan eritrosit yang menyebabkan terjadinya destruksi eritrosit (Lee et al, 2011).

Hubungan antara penyakit polikistik dengan AlHA belum begitu jelas. Pada penyakit polikistik, mutasi pada PKD-1 ataupun PKD-2 menimbulkan makrofag di darah (monosit) infiltrasi ke jaringan. Hal ini terjadi karena adanya kegagalan regulator dari imun nonspesifik di darah. keadaan tersebut akan berlanjut dan menyebabkan fragmentasi dari sel eritrosit oleh antibodi dan makrofag (Schwart dan Goldman, 2010).

Pengobatan pada pasien bersifat konservatif, dimana pemantauan fungsi ginjal dan fungsi hepar dilakukan secara berkala (Chebib and Tores, 2018). Pada pasien ini tidak dilakukan aspirasi kista karena multiple kista. Menurut literatur aspirasi kista multiple memiliki tingkat rekurensi yang tinggi, sehingga sebaiknya pada pasien ini dilakukan tindakan dengan teknik PAIR (Puncture, aspiration, injection, reaspiration) atau teknik marsupialisasi 
dengan tujuan agar rekurensi dapat dicegah (Giorgio et al, 2009).

Pasien dikonsultasi ke bagian bedah dan oleh bagian bedah digestif direncanakan dilakukan tindakan kolesitektomi dan aspirasi kista hepar secara laparoskopi. Pada pasien ini tidak dilakukan tindakah bedah karena pasien menolak rencana pembedahan. Untuk pengobatan AlHA pada pasien, diberikan terapi steroid metil prednisolone dengan dosis $0,8 \mathrm{mg} / \mathrm{kgBB} /$ hari dan dilakukan evaluasi untuk nilai hb setelah 4-6 minggu terapi.

\section{KESIMPULAN}

Penyakit ginjal polikistik autosomal dominan tidak menimbulkan gejala hingga decade keempat hidup pasien. Penyakit ini yang terjadi pada usia diatas 30 tahun dapat mengalami penyakit polikistik hepar yang ditemukan pada kasus yaitu terjadi obstruksi parsial kronik pada sistem bilier dan hal ini menimbulkan peradangan (kolesistitis) yang mencetuskan terjadi batu pada empedu. Pada pasien disertai diagnosis anemia sedang normositik normokrom ec hemolitik ec autoimun. Pemeriksaan Coomb's tes didapatkan hasil direct comb test positif.

\section{DAFTAR PUSTAKA}

Chebib FT and Torres VE, 2018. Recent advances in the Management of Autosomal Dominant Polycystic Kidney Disease. Clin J Am Soc Nephrol. 13(11): 1765-1776.

Ettorre GM, Vennarecci G, Santoro R, Laurenzi $A$, Ceribelli $C$, Cintio $A D$ et al, 2012. Giant Hydatid Cyst of The Liver With a Retroperitoneal Growth: A Case Report. Journal of Medical Case Reports. 6: 298.

Giorgio A, Sarno AD, Stefano G, Nunzia F, Paolo M, Umberto S, et al, 2009. Percutaneous Treatment of Hydatid Liver Cyst. Recent Pat Antiinfect Drug Discov. 4(1): 29-36. Purnomo BB, 2009. Dasar-Dasar Urologi. Sagung Seto, Jakarta.

Kalyani R, Thej MJ, Thomas AK, Raveesha A, 2012. Chronic Cold Agglutinin Disease: A Case Report with Review of Literature. Journal of Clinical and Diagnostic Research. (Suppl-1)6(3): 480-482.

Kelton JG, Chan h, Heddle N, Whittaker S, 2011. Acquired Hemolytic Anemia. Blood and Bone Marrow Pathology, Chapter 10, $2^{\text {nd }}$ Edition. 185-202.

Lee K, Battini L, Gusella GL., 2011. Cilium, Centrosome and Cell Cycle Regulation in Polycystic Kidney 
Penyakit Ginjal Polikistik disertai Anemia Hemolitik Autoimun

Yosa Tamia Marisa ${ }^{1 *}$, Harnavi Harun ${ }^{2}$

Disease. Biochim Biophys Acta. 1812(10): 1263-1271.

McPhee SJ and Papadakis MA, 2010. Blood disorders. Current Medical Diagnosis and Treatment. Chapter $13,50^{\text {th }}$ edition. The McGraw-Hill Companies.

Ong ACM, Devuyst O, Knebelmann B, Walz G, 2015. Autosomal Dominant Polycystic Kidney Disease: The Changing Face of Clinical
Management. 385(9981): 19932002.

Schwartz RS, Goldman L, Schafer Al, 2011. Autoimmune and Intravascular Hemolytic Anemias. Cecil Medicine, part 14.

Vachha B, Sun MRM, Siewert B, Eisenberg RL, 2011. Cystic Lesions of The Liver. American Journal of Roentgenology. 196(4): 355-366. 